\title{
Seroepidemiology of Sarcocystis neurona, Toxoplasma gondii and Neospora spp. among horses in the south of the state of Minas Gerais, Brazil
}

\author{
Soroepidemiologia de Sarcocystis neurona, Toxoplasma gondii e Neospora spp. em \\ Equinos no Sul do Estado de Minas Gerais, Brasil
}

Manoel Junqueira Maciel Ribeiro'; Marina Helena Figueredo Rosa'; Fábio Raphael Pascoti Bruhn²;

Adriana de Mello Garcia ${ }^{3}$; Christiane Maria Barcellos Magalhães da Rocha ${ }^{3}$ Antônio Marcos Guimarães ${ }^{3 *}$

\author{
${ }^{1}$ Programa de Pós-graduação em Ciências Veterinárias, Universidade Federal de Lavras - UFLA, Lavras, MG, Brasil \\ ${ }^{2}$ Departamento de Veterinária Preventiva - DVP, Faculdade de Veterinária, Universidade Federal de Pelotas - UFPel, Capão do Leáo, \\ RS, Brasil \\ ${ }^{3}$ Departamento de Medicina Veterinária - DMV, Universidade Federal de Lavras - UFLA, Lavras, MG, Brasil
}

Received October 29, 2015

Accepted March 2, 2016

\begin{abstract}
The present study used the indirect fluorescent antibody test (IFAT) to determine the seroprevalence of Sarcocystis neurona, Toxoplasma gondii and Neospora spp., and evaluated the variables associated with these infections among 506 apparently healthy horses, reared in the south of the state of Minas Gerais, Brazil. This study was conducted between April 2012 and October 2013. Among the horses, the true prevalence of S. neurona was 26\% (95\% CI: 22.0-30.4\%), T. gondii 19.9\% (95\% CI: 15.5-24.8\%) and Neospora spp. 23.9\% (95\% CI: 19.9-28.1\%); and among the farms, $88.3 \%$ (95\% CI: 74.4-91.6\%), 71.6\% (95\% CI: 41-92.8\%) and 85\% (95\% CI: 70.7-96.1\%), respectively. Regarding mixed infection, 17 horses (3.4\%) were seropositive for both S. neurona and T. gondii, 16 (3.2\%) for T. gondii and Neospora spp. and $14(2.8 \%)$ for $S$. neurona and Neospora spp. The associations between seropositivity and variables relating to the structure of the farm, management and health were analyzed using the logistic regression analysis, through the generalized estimating equations (GEE). The results suggest that the south of Minas Gerais is an enzootic area for S. neurona, T. gondii and Neospora spp. among horses, with prevalence of asymptomatic subclinical or chronic infections.

Keywords: Apicomplexa, Sarcocystidae, indirect immunofluorescence, risk factors.
\end{abstract}

\section{Resumo}

Este estudo determinou, pela reação de imunofluorescência indireta (RIFI), a soroprevalência de Sarcocystis neurona, Toxoplasma gondii e Neospora spp., e avaliou as variáveis associadas com a infecção, em 506 equinos, aparentemente sadios, criados no Sul de Minas, Brasil. O estudo foi realizado no período de abril de 2012 a outubro de 2013. Entre equinos, a prevalência verdadeira para S. neurona foi de 26\% (IC 95\%= 22,0-30,4\%); para T. gondii de 19,9\% (IC 95\%= 15,5-24,8\%); e para Neospora spp. de 23,9\% (IC 95\%= 19,9-28,1\%); e entre propriedades, 88,3\% (IC 95\%= 74,4-91,6\%), 71,6\% (IC 95\% = 41-92,8\%), e 85\% (IC 95\%= 70,7-96,1\%), respectivamente. Em relação à infecção mista, 17 (3,4\%) equinos foram soropositivos para S. neurona e T. gondii, 16 (3,2\%) para T. gondii e Neospora spp., e 14 (2,8\%) para S. neurona e Neospora spp. A associação entre soropositividade e variáveis relacionadas à estrutura da propriedade, manejo e sanidade, foi analisada, utilizando-se a análise de regressão logística estimada por Generalized Estimating Equations (GEE). Os resultados sugerem que o Sul de Minas é área enzoótica para S. neurona, T. gondii e Neospora spp. em equinos, com predomínio de infecçóes subclínicas ou crônicas, assintomáticas.

Palavras-chave: Apicomplexa, Sarcocystidae, imunofluorescência indireta, fatores de risco. 


\section{Introduction}

Brazil possesses one of the largest horse herds in the world, with approximately 5.3 million head. Horse-rearing is an important source of income and employment. In the southern region of the state of Minas Gerais, horse rearing occupies an important space in the local economic, touristic, historic and cultural scene, since this was the birthplace of the Mangalarga Marchador horse breed, which is internationally admired (IBGE, 2013).

Equine protozoal myeloencephalitis, caused by Sarcocystis neurona, is a disease characterized by a neurological condition in which horses participates as an accidental host. In Brazil, the seroprevalence of $S$. neurona among horses has been estimated in $37.7 \%$ (Western blot) (LINS et al., 2012) and 33.7\% (ELISA) (PIVOTO et al., 2014) in Rio Grande do Sul, and 8.75\% (IFAT) in Rio de Janeiro (STELMANN, 2014). Worldwide seroprevalence varies between $0 \%$ and $89.2 \%$ (DUBEY et al., 2015).

Toxoplasmosis, the disease caused by Toxoplasma gondii, is a zoonosis of global interest due to its impact on public health. It can be transmitted through consumption of raw or undercooked meat, including horse meat (DUBEY \& SU, 2009). The levels of antibodies for T. gondii among horses in Brazil has been estimated in $12.8 \%$ (IFAT) in Minas Gerais (NAVES et al., 2005), 2.5\% (IFAT) in Mato Grosso do Sul (LASKOSKI et al., 2015) and 28,4\% (IFAT) in states of Alagoas, Paraíba, Pernambuco, Rio Grande do Norte and Minas Gerais (GENNARI et al., 2015). Worldwide, seroprevalence varies between $0 \%$ and $72.2 \%$ (ALSHAHERY \& MANSOUR, 2012; MATSUO et al., 2014).

Neosporosis is a parasitic disease caused by the protozoon Neospora caninum, which can infect several mammals, including horses, and by $N$. hughesi, which infects horses and is an uncommon etiological agent for equine protozoal myeloencephalitis (GOODSWEN et al., 2013). In Brazil, the prevalence of anti-Neospora spp. antibodies among horses has been estimated in 57.6\% (IFAT) in São Paulo (STELMANN et al., 2011), 25.7\% (IFAT) in Santa Catarina (ABREU et al., 2014), and $1.87 \%$ (IFAT) in Rio de Janeiro (STELMANN, 2014) and, abroad, from 0\% to 35\% (DUBEY et al., 1999; PATITUCCI et al., 2004).
These three protozoa of the phylum Apicomplexa, family Sarcocystidae, are transmitted through consumption of water and food contaminated by sporocysts, in the case of $S$. neurona, and sporulated oocysts, in the cases of T. gondii and Neospora spp., which are released by the definitive hosts: respectively, possums, felids and canids (LANGONI et al., 2007; DUBEY \& SU, 2009; DUBEY et al., 2015). The infection is usually asymptomatic among horses, but may sporadically present nervous symptoms in the cases of $S$. neurona, $T$. gondii and $N$. hughesi, and reproductive disorders, when involving $T$. gondii and $N$. caninum (LOCATELLIDITTRICH et al., 2006; GENNARI et al., 2015).

Because of the importance of horse-rearing in the south of the state of Minas Gerais, determining the prevalences of $S$. neurona, T. gondii and Neospora spp., along with the factors associated with these infections, is fundamental for implementing effective control measures, so as to reduce the exposure of the animals and prevent the economic losses caused by these parasites. Moreover, this type of investigation increases the knowledge on the distribution of these agents among the horse population nationally.

Thus, due to the scarcity of studies in Brazil and lack of information regarding equine infection in the southern part of the state of Minas Gerais, the present study had the objectives of determining the prevalence of S. neurona, T. gondii and Neospora spp., and identifying possible factors associated with seropositivity among Mangalarga Marchador horses.

\section{Materials and Methods}

\section{Study area and animals}

Blood samples were gathered from 506 Mangalarga Marchador horses that had been reared on 53 farms that were distributed among 27 municipalities in the microregions of Andrelândia, Lavras, São João Del Rey, São Lourenço and Varginha, in the southern portion of the state of Minas Gerais (Figure 1). The study was conducted between April 2012 and October 2013 after approval had been obtained from the Ethics Commission for Animal Use (COEA)
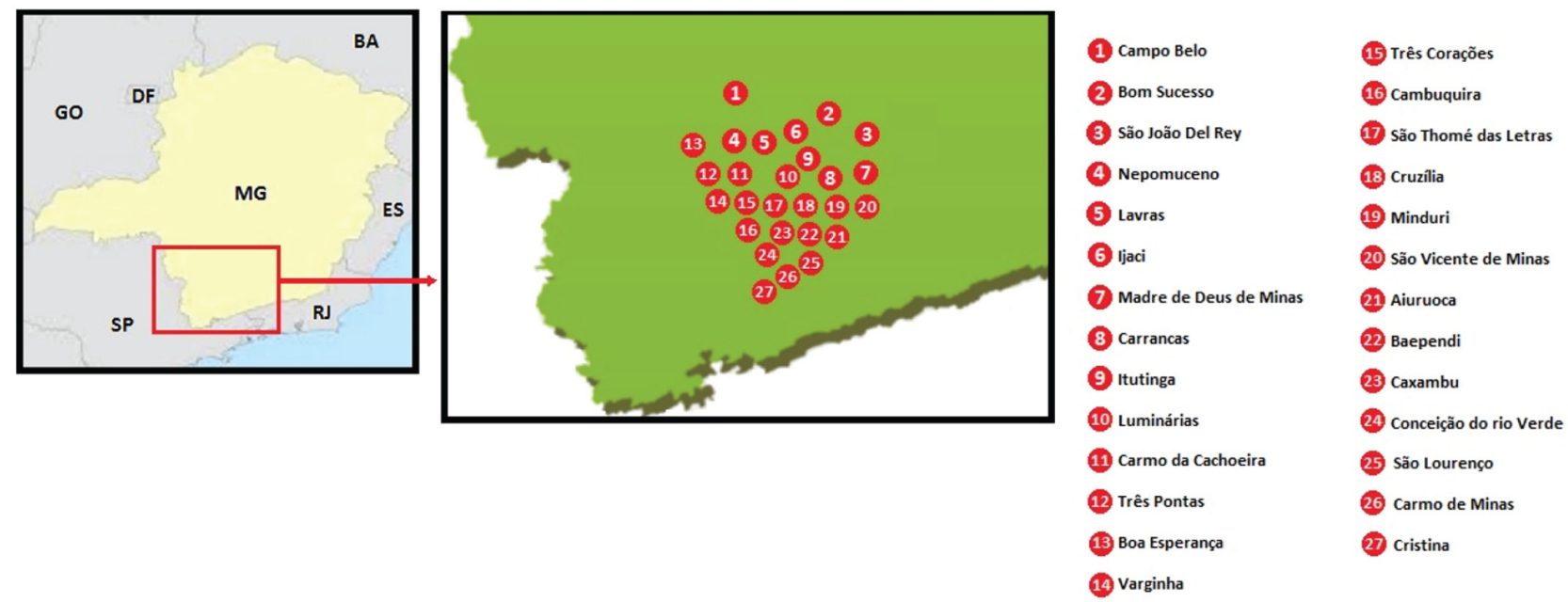

Figure 1. Map of the state of Minas Gerais, Brazil, highlighting the location of the municipalities of the southern region that were involved in the study. 
of the Federal University of Lavras (UFLA), and was registered at this institution under number $023 / 11$.

The farms were chosen randomly based on guidance from the Brazilian Association of Mangalarga Marchador Horse Breeders (Associação Brasileira de Criadores de Cavalos Mangalarga Marchador, ABCCMM). In this sampling, the proportions between the mesoregions and the sizes of farms and their structures were maintained in order to attain homogeneous representativeness. At least ten horses from each farm were required for the prevalence calculation on S. neurona, T. gondii and Neospora spp. In addition, pregnant mares and foals of less than six months of age were not included in the sampling. The reasons were that pregnant mares are more sensitive to manipulation, while foals younger than six months may present colostral antibodies (passive immunity), which would interfere with the serological diagnosis. The blood samples were obtained by means of jugular venipuncture and were collected in Vacutainer tubes. All the animals appeared to be healthy. After centrifugation at $500 \mathrm{~g}$ for 10 minutes, the serum samples from 506 horses were stored in individually identified cryotubes and frozen at $-20{ }^{\circ} \mathrm{C}$ until the serological tests were performed.

The definition of the number of horses (n) needed to estimate the prevalence was based on the formula of the Pan-American Zoonosis Center (CEPANZO, 1979), which is appropriate for calculating samples for research on chronic diseases: $\mathrm{n}=\left[\mathrm{p} \times(100-\mathrm{p}) \times \mathrm{Z}^{2}\right] /(\mathrm{d} \times \mathrm{p} / 100)^{2}$. Considering an estimated prevalence (p) of 50\%, a $95 \%$ confidence interval (z) of 1.96 and an acceptable error margin (d) of $10 \%$, the minimum number (n) of horses was 384 .

\section{Information-gathering on the farms}

A questionnaire-based interview was carried out with either the owners or the person responsible for each farm. The questions related to herd health, the breeder, management and the structure of the farm. Moreover, questions asking about any history of reproductive problems and the neurological condition of the herds were also devised. This information served as independent variables for subsequent analyses that evaluated the associations between seropositivity to the protozoa and factors relating to sociocultural information, herd health and management practices observed on the farms. In total, 305 variables were analyzed, which were obtained by means of the questionnaire.

\section{Serological tests}

The indirect fluorescent antibody test (IFAT) was the method chosen for investigating anti-S. neurona, T. gondii and Neospora spp. IgG antibodies. This is considered to be the gold-standard test for serologically diagnosing the latter two protozoa (LANGONI et al., 2007; DUBEY \& SCHARES, 2011).

In investigating anti-S. neurona antibodies, the IFAT was performed as described by Johnson et al. (2013). The antigens were $S$. neurona merozoites, produced in cell cultures. Ten microliters of S. neurona merozoite solution was placed in each one of the 12 slide wells for IFAT (about 10 merozoites / field at 40x magnification in an optical microscope). After slides had been dried at room temperature, they were stored in a freezer at $-20{ }^{\circ} \mathrm{C}$ until the time of use. The IFAT for T. gondii was performed using the technique described by Langoni et al. (2007) and the antigens were the tachyzoites of the parasite. After successive inoculations, the tachyzoites were recovered through rinsing the peritoneal cavity of mice with a saline solution. Ten microliters of a solution containing tachyzoites was placed in each of the 12 slide wells for IFAT (about 10 tachyzoites / field at 40x magnification in an optical microscope). After the slides had been dried at room temperature, they were stored in a freezer at $-20{ }^{\circ} \mathrm{C}$ until the time of the serological tests. In the present study, $N$. caninum tachyzoites were used as the antigen in the IFAT, and their antibodies presented cross-reactions with $N$. hughesi (GONDIM et al., 2009). The IFAT for Neospora spp. was performed in accordance with the technique described by Paré et al. (1995), using glass slides containing tachyzoites of $N$. caninum as the antigen (Laboratório Imunodot, Jaboticabal, Brazil).

An equine anti-IgG conjugate (SIGMA, Saint Louis, MO, USA) was used for performing the IFAT, at a dilution of 1:64, along with positive (serum samples of mares seropositive to $S$. neurona, T. gondii and Neospora spp.) and negative (serum samples of newborn foal before colostrum ingestion and serum samples of periparturient mare, both seronegative to respective protozoa) controls for the respective protozoa. The serum samples were considered positive if they presented complete fluorescence of the $S$. neurona merozoites at a dilution of 1:80 (DUBEY et al., 2015), and of the T. gondii and Neospora spp. tachyzoites, respectively, at dilutions of 1:64 (ABREU et al., 2014) and 1:50 (LOCATELLI-DITTRICH et al., 2006). Both the IFAT and the preparation of slides containing S. neurona and T. gondii antigens were performed at the Parasite Disease Laboratory of the Federal University of Lavras (UFLA).

\section{Statistical analyses}

The EpiData software was used to tabulate the data relating to the variables studied. These data were later ranked and analyzed using the statistical software SPSS 20.0 statistical software (IBM, 2011). In calculating true prevalence (TP) for the anti-S. neurona antibodies, values of $94 \%$ and $88.9 \%$ were used for sensitivity (SE) and specificity (SP), respectively, as prescribed by Duarte et al. (2003). In the case of TP for T. gondii, the SE and SP values were, respectively, $90.9 \%$ and $100 \%$ (LU et al., 2013). In turn, TP for Neospora spp. presented values of $91.0 \%$ and $99.0 \%$, respectively, for SE and SP, in accordance with Björkman \& Uggla (1999).

Subsequently, the SE and SP between the herds were used to calculate the TP at herd level (NOORDHUIZEN et al., 2001), by means of the epidemiological calculators of the Epitools software (SERGEANT, 2011). The variables relating to the structural, sanitary and management characteristics of the farms, along with the inherent characteristics of the animals, were firstly subjected to the chi-square test or Exact Test of Fisher (less than five observations in any category) using the SPSS 20.0 software (IBM, 2011), so as to demonstrate their association with the seropositivity of the studied agents. This association, when statistically significant, was quantified by the odds ratio and its confidence interval at 95\% (CI. 95\%), which estimates the risk relationship between 
independents variables (risk or protective factors) and the dependent variables (serology results). Variables that presented p values $<0.05$ were considered significant, meaning that they were statistically associated with seropositivity to $S$. neurona, T. gondii and Neospora spp. Subsequently, the variables that presented p values $<0.20$ in the chi-square test or Exact Test of Fisher were subjected to the logistic regression analysis, through the generalized estimating equations (GEE) (CORBELLINI et al., 2006; BRUHN et al., 2013). Variables that presented $p$ values $<0.05$ in the GEE were considered to be significantly associated with seropositivity for S. neurona, T. gondii and Neospora spp.

The QIC (Quasilikelihood under the Independence model Criterion) and the related QICC statistics, proposed by Pan (2001) as GEE logistic regression goodness of fit measure, was used to compare the GEE models, considering that when QICC approximates QIC the GEE model is correctly specified and that the model with the smaller QIC and QICC statistics is preferred.

\section{Results}

\section{Farm profile}

Among the 506 animals analyzed, 343 were female (67.8\%) and 163 were male $(32.2 \%)$. There were 61 foals $(12.1 \%)$ and 445 adults (87.9\%). Among the 53 farms, horse-rearing was the main activity on only 21 of them (39.6\%). Regarding size, 27 farms (51.0\%) covered more than 100 ha, with a mean area of 199.1 ha. Forty-eight farms (90.6\%) either bordered or included a forest or woodland reserve. Regarding the objective of the horse-rearing, 40 farmers $(75.3 \%)$ reared horses for commercial purposes, and 34 (64.1\%) for commercial purposes and reproduction. Forty-eight farms $(90.6 \%)$ reared both horses and cattle, concomitantly, among which 22 (45.8\%) combined the two species in the same pasture. On 47 farms (88.7\%), there were other animals besides horses and cattle, with the presence of dogs on 45 farms (84.9\%). Interaction between the different species of animals occurred in $39(73.6 \%)$ herds, to a greater or lesser degree. Regarding the farming system, 36 farmers $(67.9 \%)$ maintained their animals exclusively in picket-fenced enclosures. Considering food management, 47 farms (88.7\%) used grass and also offered feed to the animals, among which 21 (44.7\%) manufactured the concentrate on-site. Regarding sanitary management, 50 farmers (94.3\%) vaccinated their animals, and 31 (58.5\%) had veterinary assistance. Most of the farms used artificial insemination techniques (62.3\%). Horserearing was the main source of income on 13 farms $(24.5 \%)$, and $33(62.3 \%)$ had been conducting this activity for over 20 years.

\section{Seroprevalence and variables associated with infection}

Sarcocystis neurona. Out of the 506 horses, 117 (23.0\%) presented anti-S. neurona antibodies, with true prevalence (TP) of $26.0 \%$ (95\% CI: $22.0-30.4 \%$ ). Out of the 53 properties analyzed, 44 had at least one seropositive horse, with TP of $88.3 \%$ (95\% CI: 74.4-91.6\%). As shown in Table 1, the properties that included forest reserves or that bordered a reserve presented a high risk ( $\mathrm{p}<0.05)$ of having horses seropositive for $S$. neurona. Farms that manufactured their own feed also had greater risk $(\mathrm{p}<0.05)$ of having infected horses.

Toxoplasma gondii. In the case of T. gondii, 107 (21.1\%) horses were seropositive, representing a TP of $19.9 \%(95 \%$ CI: $15.5-24.8 \%)$. On 45 farms, at least one horse was seropositive, indicating a TP of 71.6\% (95\% CI: 41.0-92.8\%). Farms that had more than 100 horses presented lower risk $(\mathrm{p}<0.05)$ of having infected animals. Farms that vaccinated their horses against tetanus and influenza, and those that had an area for treating, cleaning and caring for the animals, presented lower risk $(\mathrm{p}<0.05)$ of infection. Horses over the age of five years were significantly ( $\mathrm{p}<0.05$ ) more liable to infection by $T$. gondii (Table 2 ). There was a significant association $(\mathrm{p}<0.05)$ between the use of embryo transference and seropositivity, both through the Exact Test of Fisher or chi-square test and through the multivariate analysis using the generalized estimating equations (GEE). In this latter test, horses on farms that did not use embryo transference had twice as much risk of infection (95\% CI: 1.086-3.003) as farms that did use this technique $(\mathrm{p}=0.023)$.

Neospora spp. The TP for Neospora spp. was 23.9\% (95\% CI: $19.9-28.1 \%$ ), with 105 seropositive horses. On the farms, the TP was 85\% (95\% CI: 70.7-96.1\%), with at least one positive animal on 41 farms. Farms in the southern part of the state of Minas Gerais that offered hay to their horses presented lower risk

Table 1. Epidemiological variables associated with antibodies for $S$. neurona (IFAT 1:80), in the univariate analysis $(\mathrm{P}<0.05)$, among horses reared in the southern part of the state of Minas Gerais, Brazil.

\begin{tabular}{|c|c|c|c|c|c|c|c|}
\hline \multirow{3}{*}{ Factors } & \multicolumn{4}{|c|}{ Sarcocystis neurona } & \multirow{3}{*}{$\begin{array}{c}\text { Odds } \\
\text { ratio }(\mathrm{OR})\end{array}$} & \multirow{3}{*}{$95 \% \mathrm{CI}$} & \multirow{3}{*}{$\mathbf{P}^{*}$} \\
\hline & \multicolumn{2}{|c|}{ Positive } & \multicolumn{2}{|c|}{ Negative } & & & \\
\hline & $\mathbf{n}$ & $\%$ & $\mathbf{n}$ & $\%$ & & & \\
\hline Feed manufactured on the farm $\left(\mathrm{n}=47^{* *}\right)$ & & & & & & & 0.026 \\
\hline No & 13 & 65.00 & 7 & 35.00 & 1 & & \\
\hline Yes & 25 & 92.59 & 2 & 7.41 & 6.731 & $1.219-37.155$ & \\
\hline Farm includes or borders a forest reserve $(n=53)$ & & & & & & & 0.030 \\
\hline No & 2 & 33.33 & 3 & 66.67 & 1 & & \\
\hline Yes & 42 & 87.50 & 6 & 12.50 & 10.500 & $1.445-76.289$ & \\
\hline
\end{tabular}

IFAT: indirect fluorescent antibody test; CI: confidence interval. *Exact Test of Fisher $(\mathrm{P}<0.05) .{ }^{* *}$ Six farms did not use feed. There was no significant association $(\mathrm{P}>0.05)$ between seropositivity and the following variables: sex; age; keeping horses in stables; and purpose of horse-rearing. 
( $\mathrm{p}<0.05$ ) of having animals seropositive for Neospora spp. Farms on which the horses were in contact with other animals, or in which horses over the age of five years were present, presented greater risk $(\mathrm{p}<0.05)$ of infection (Table 3$)$. Horses on farms on which cattle and cats were also present showed greater risk ( $\mathrm{p}<0.05$ ) of being infected by Neospora spp., from the multiple logistic regression through the generalized estimating equations (GEE) (Table 4).

\section{Mixed infection}

Mixed infection by $S$. neurona and T. gondii occurred in 3.4\% (17/506) of the horses, while 3.2\% (16/506) were positive for both T. gondii and Neospora spp. Horses infected by $S$. neurona and Neospora spp. represented 2.8\% (14/506) of the sample. Infection involving the three agents occurred among only $1.4 \%(7 / 506)$ of animals. In $11.3 \%(6 / 53)$ of the farms there was positivity for all

Table 2. Epidemiological variables associated with antibodies for $T$. gondii (IFAT 1:64), in the univariate analysis $(\mathrm{P}<0.05)$, among horses reared in the southern part of the state of Minas Gerais, Brazil.

\begin{tabular}{|c|c|c|c|c|c|c|c|}
\hline \multirow{3}{*}{ Factors } & \multicolumn{4}{|c|}{ Toxoplasma gondii } & \multirow{3}{*}{$\begin{array}{c}\text { Odds } \\
\text { ratio }(\mathrm{OR})\end{array}$} & \multirow{3}{*}{$95 \% \mathrm{CI}$} & \multirow{3}{*}{$\mathbf{P}^{*}$} \\
\hline & \multicolumn{2}{|c|}{ Positive } & \multicolumn{2}{|c|}{ Negative } & & & \\
\hline & $\mathbf{n}$ & $\%$ & $\mathbf{n}$ & $\%$ & & & \\
\hline Total number of horses on the farm $(n=53)$ & & & & & & & 0.033 \\
\hline$>100$ animals & 6 & 60.00 & 4 & 40.00 & 1 & & \\
\hline$<100$ animals & 39 & 90.69 & 4 & 9.31 & 6.493 & $1.272-33.333$ & \\
\hline Vaccine against tetanus $(\mathrm{n}=53)$ & & & & & & & 0.038 \\
\hline Yes & 3 & 50.00 & 3 & 50.00 & 1 & & \\
\hline No & 42 & 89.36 & 5 & 10.64 & 8.403 & $1.321-52.631$ & \\
\hline Vaccine against influenza $(\mathrm{n}=53)$ & & & & & & & 0.014 \\
\hline Yes & 12 & 66.66 & 6 & 33.34 & 1 & & \\
\hline No & 33 & 94.28 & 2 & 5.72 & 8.264 & $1.459-47.619$ & \\
\hline Use of embryo transfer $(n=53)$ & & & & & & & 0.017 \\
\hline Yes & 17 & 70.83 & 7 & 29.17 & 1 & & \\
\hline No & 28 & 96.55 & 1 & 3.45 & 11.494 & $1.303-99.999$ & \\
\hline Use of a treatment, cleaning and care area for the animals $(\mathrm{n}=53)$ & & & & & & & 0.050 \\
\hline Yes & 20 & 74.07 & 7 & 25.93 & 1 & & \\
\hline No & 25 & 96.15 & 1 & 3.85 & 8.771 & $0.993-76.923$ & \\
\hline Age of the animals $\left(\mathrm{n}=485^{* *}\right)$ & & & & & & & 0.011 \\
\hline$<5$ years & 36 & 16.29 & 185 & 83.71 & 1 & & \\
\hline$>5$ years & 68 & 25.76 & 196 & 74.24 & 1.783 & $1.135-2.799$ & \\
\hline
\end{tabular}

IFAT: indirect fluorescent antibody test; CI: confidence interval. *Exact Test of Fisher and chi-square test $(\mathrm{P}<0.05) .{ }^{* *}$ The ages of 21 horses were not informed. There was no significant association $(\mathrm{P}>0.05)$ between seropositivity and the following variables: presence of cats; rearing purpose and system; sex; and rearing of horses and cattle together.

Table 3. Epidemiological variables associated with antibodies for Neospora spp. (IFAT 1:50), in the univariate analysis (P < 0.05), among horses reared in the southern part of the state of Minas Gerais, Brazil.

\begin{tabular}{|c|c|c|c|c|c|c|c|}
\hline \multirow{3}{*}{ Factors } & \multicolumn{4}{|c|}{ Neospora spp. } & \multirow{3}{*}{$\begin{array}{c}\text { Odds } \\
\text { ratio }(\mathrm{OR})\end{array}$} & \multirow{3}{*}{$95 \% \mathrm{CI}$} & \multirow{3}{*}{$\mathbf{P}^{*}$} \\
\hline & \multicolumn{2}{|c|}{ Positive } & \multicolumn{2}{|c|}{ Negative } & & & \\
\hline & $\mathbf{N}$ & $\%$ & $\mathbf{n}$ & $\%$ & & & \\
\hline Supply of hay $(\mathrm{n}=53)$ & & & & & & & 0.045 \\
\hline Yes & 13 & 61.90 & 8 & 38.10 & 1 & & \\
\hline No & 28 & 87.50 & 4 & 12.50 & 4.310 & $1.096-16.949$ & \\
\hline Contact between horses and other animals $(n=53)$ & & & & & & & 0.008 \\
\hline No & 7 & 50.00 & 7 & 50.00 & 1 & & \\
\hline Yes & 34 & 87.18 & 5 & 12.82 & 6.800 & $1.666-27.761$ & \\
\hline Age of the animals $\left(\mathrm{n}=485^{* *}\right)$ & & & & & & & 0.034 \\
\hline$<5$ years & 37 & 16.74 & 184 & 83.26 & 1 & & \\
\hline$>5$ years & 65 & 24.62 & 199 & 75.38 & 1.624 & $1.035-2.549$ & \\
\hline
\end{tabular}

IFAT: indirect fluorescent antibody test; CI: confidence interval. *Exact Test of Fisher and chi-square test $(\mathrm{P}<0.05) .{ }^{* *}$ The ages of 21 horses were not informed. There was no significant association $(\mathrm{P}>0.05)$ between seropositivity and the following variables: presence of dogs on the property; sex of the animals; and occurrence of either reproductive or neurological disorders in the equine herds. 
Table 4. Epidemiological variables associated with antibodies for Neospora spp. (IFAT 1:50), in the multiple logistic regression analysis using the generalized estimate equations, among horses reared in the southern part of the state of Minas Gerais, Brazil.

\begin{tabular}{|c|c|c|c|c|c|c|c|}
\hline \multirow{3}{*}{ Factors } & \multicolumn{4}{|c|}{ Neospora spp. } & \multirow{3}{*}{$\begin{array}{c}\text { Adjusted Odds } \\
\text { Ratio (OR) }\end{array}$} & \multirow{3}{*}{ CI 95\% (OR) } & \multirow{3}{*}{$\mathbf{P}$} \\
\hline & \multicolumn{2}{|c|}{ Positive } & \multicolumn{2}{|c|}{ Negative } & & & \\
\hline & $\mathbf{n}$ & $\%$ & $\mathbf{n}$ & $\%$ & & & \\
\hline Presence of cattle $(n=53)$ & & & & & & & 0.007 \\
\hline No & 2 & 40.00 & 3 & 60.00 & 1 & & \\
\hline Yes & 39 & 81.25 & 9 & 18.75 & 5.280 & $1.585-17.598$ & \\
\hline Presence of cats $(n=53)$ & & & & & & & 0.045 \\
\hline No & 21 & 67.74 & 10 & 32.26 & 1 & & \\
\hline Yes & 15 & 93.75 & 1 & 6.25 & 1.881 & $1.015-3.485$ & \\
\hline
\end{tabular}

IFAT: indirect fluorescent antibody test; CI: confidence interval. QIC (Quasilikelihood under the Independence model Criterion): 448.2; QICC: 446.4 (The QIC and QICC was used as GEE logistic regression goodness of fit measure, considering that when QICC approximates QIC the GEE model is correctly specified and that the model with the smaller QIC and QICC statistics was preferred).

three agents, and all farms presented horses infected by at least one protozoon. However, $47.2 \%(239 / 506)$ of the horses were seronegative for all three parasites.

\section{Discussion}

\section{Farm profile}

Most of the farms presented interaction between different animals, mostly between horses and cattle and/or dogs, which were the two predominant species on these farms. Moreover, the herds were mostly located in pastures and near woodlands, thus allowing contact with wild fauna and, consequently, favoring exposure of the horses to the parasites studied in this investigation (ABREU et al., 2014; DUBEY et al., 2015). Most of the horses were reared for commercial purposes, thus allowing a large flow of animals, which favors dispersion of the agents (MOURA et al., 2013). The majority of the farms showed good sanitary practices, such as vaccinating the animals, sanitizing the installations, storing food adequately and having veterinarian assistance. This demonstrated the owners' concern for caring for the herd's health, which could have influenced the seroprevalence rates of the agents analyzed and the absence of clinical symptomatology among the animals.

\section{Seroprevalence and variables associated with infection}

Sarcocystis neurona. The prevalence of $S$. neurona among horses $(26.0 \%)$ was within the range observed in previous studies conducted in Brazil, 37.7\% (Western blot) in Rio Grande do Sul (LINS et al., 2012) and 8.3\% (IFAT) in Rio de Janeiro (STELMANN, 2014), and worldwide, same 26.1\% (Western blot) in Argentina (MORÉ et al., 2014) and 27.6\% (IFAT) in EUA (PUSTERLA et al., 2014). The high prevalence among herds $(88.3 \%)$ can be explained by the fact that most horses were reared in picket-fenced enclosures, thus facilitating their contact with wild fauna, which predisposed the animals towards infection by $S$. neurona (MORLEY et al., 2008). In addition, the presence of woodlands near the pastures in the absolute majority of the farms $(90.57 \%)$, probably increased the risk of contact between horses and wild animals, such as possums (DUBEY et al., 2015).
The possum (Didelphis albiventris) is a broadly distributed animal in South America for which primary and secondary woodlands are its natural habitat (ORR, 1986). Given its high synanthropy, this species is a potential disseminator of pathogens between domestic animals and man (MULLER et al., 2005). This would explain the association between the presence of forest reserves either on the farms or bordering the farms and seropositivity for $S$. neurona, which has also been reported in other studies (MORLEY et al., 2008; DUBEY et al., 2015). The greater risk of infected animals found on farms that manufactured their own feed suggests that the storage of the raw material used in the formulation was inadequate, thus allowing access by wild animals (possums) to the food (MORLEY et al., 2008).

Toxoplasma gondii. The prevalence of anti-T. gondii antibodies among the horses (19.9\%) was within the range observed in serological studies carried in Brazil, 31.5\% (IFAT) in states of Mato Grosso, Mato Grosso do Sul, Paraná and São Paulo (VIDOTTO et al., 1997), and 2.1\% (IFAT) in Rio de Janeiro (STELMANN, 2014), and same $17.7 \%$ (IFAT) in Paraná (FINGER et al., 2013), and abroad, 2.6\% (IFAT) in South Korea (GUPTA et al., 2002) and $40.5 \%$ (IFAT) in Egypt (GHAZY et al, 2007). The high prevalence among farms $(71.6 \%)$ indicated that there was wide dispersion of the parasite in the region. Thus, we can infer that positive farms (those with at least one seropositive equine) had potential risk factors for infection with $T$. gondii. Considering the intense movement of horses between farms, as most farms had animals that participated in commercial events, which may have predisposed the animals towards infection by $T$. gondii, as suggested by Kouam et al. (2010).

In the present study, the lower risk of seropositivity for T. gondii that was found on farms with more than 100 horses can be partly explained by the fact that these larger farms were technologically driven and their owners were better informed. On the other hand, the precarious manner of storing the food offered to the horses (DUBEY \& SU, 2009), as well as environmental conditions favorable towards development and survival of parasites (KOUAM et al., 2010), helps to explain the greater risk of contamination of horses on small farms.

Although there was no direct relationship with the form of transmission of $T$. gondii, the lower risk of seropositivity observed in farms that had their animals vaccinated against tetanus and 
influenza, or that used a specific area to care for the animals, allows the inference that the owners are concerned about the health of their animals. Thus, use of hygienic care and sanitary measures, including those that are protection factors against other agents and not directly against $T$. gondii, indirectly contribute towards reducing the risk of exposure or preventing immunosuppressant coinfections, which would be able to increase the risk of infection though this parasite (TASSI, 2007).

Greater seropositivity among horses over the age of five years can be explained by the fact that older animals have had more chances of becoming exposed to $T$. gondii over the course of their lives and, consequently, of becoming infected and producing antibodies against this protozoon.

The farms in the south of the state of Minas Gerais that used embryo transfer techniques presented lower risk of horses becoming infected by T. gondii. Embryo transfer is a modern form of animal reproduction technology and is not directly related to transmission of $T$. gondii. However, we can infer that these properties were more technologically-oriented, with use of good hygiene-sanitary practices capable of controlling various illnesses on the farm, and that either directly or indirectly, these practices contributed towards reducing the risk of horse infections by $T$. gondii. Thus, these farms were better prepared to implement preventive measures against T. gondii, such as safe storage of food and hygiene of installations (DUBEY \& SU, 2009). Thus, these farms avoided environmental conditions that would favor development and survival of parasite oocysts, such as warm and humid locations (LANGONI et al., 2007; KOUAM et al., 2010).

Although the presence of cats on the farm is a risk factor (DUBEY \& SU, 2009), this situation was not observed in the present study, as also reported by Stelmann (2014). The presence of seronegative cats on the farms and/or intense traffic of animals in the region could explain the absence of this correlation (LANGONI et al., 2007). There was no significant association between sex, rearing purpose or rearing system (stable or pasture) and seropositivity, and thus our results were in agreement with those of Stelmann (2014), although in disagreement with those of Kouam et al. (2010).

Neospora spp. The seroprevalence of Neospora spp. (23.9\%) among the horses was within the range observed in other studies (IFAT) carried out in Brazil, 57.6\% (IFAT) in São Paulo (STELMANN et al., 2011) and 4.1\% (IFAT) in Santa Catarina (MOURA et al., 2013), and same $25.7 \%$ (IFAT) in Santa Catarina (ABREU et al., 2014), and abroad, 8.9\% (IFAT) in Israel (KLIGLER et al., 2007) and $28.0 \%$ (IFAT) in Italy (CIARAMELLA et al., 2004), and same 24,0\% (ELISA) in Czech Republic (BÁRTOVÁ et al., 2010). The wide distribution of the infection among the farms $(85.0 \%)$ was probably due to the environmental conditions of the southern part of the state of Minas Gerais, typical of Brazilian tropical regions, which favor sporulation of Neospora spp. oocysts (MOURA et al., 2013).

The association between seropositivity for Neospora spp. and "no supply of hay" suggests that farms that are able to provide hay for their horses are more technologically-oriented and their owners are better informed. Thus, these owners take greater care regarding storage and supply of food, thereby minimizing the risk of animal infection. Moreover, hay is a source of roughage, which indicates that on the farms where hay is supplied as food, there is greater confinement of the animals in stalls and lower contact with pastures. Thus, there is a lower risk of contact between the horses in stables and the definitive hosts (ABREU et al., 2014).

Greater positivity of Neospora spp. among horses above the age of five years suggests that horizontal transmission predominates, considering that only $16.7 \%(37 / 221)$ of the animals below the age of five years were infected. This lower efficiency of congenital transmission among horses, in comparison with cattle, can be partly explained by placentation differences (PITEL et al., 2003).

In the south of the state of Minas Gerais, horse farms with the presence of cattle presented a significant association with infection by Neospora spp. These results corroborate the findings of Moura et al. (2013) and Abreu et al. (2014), thus suggesting that cattle are able to maintain the agent on the farms, since dogs commonly have access to bovine meat and their placental remains.

The significant association between seropositivity for the agent and the presence of cats in the farms suggests that there is greater presence of rodents on these farms. These animals can act as intermediate hosts for Neospora spp. and are able to maintain the parasite's cycle on the farm and infect dogs, which due to their carnivorous habit, hunt these rodents. A similar result was observed by Stelmann (2014), who correlated equine neosporosis with access of cats to food. Although there are studies that have correlated infection by Neospora spp. with the presence of dogs and contact between them and horses (MOURA et al., 2013), this was not shown on these farms in the southern part of the state of Minas Gerais. This result may suggest that the dogs were probably not infected, or were not in the habit of feeding off placental remains and tissues of the animals.

In the present study there was no significant association between sex and seropositivity to Neospora spp., which was also observed previously by Moura et al. (2013). Similarly, animals with a history of either reproductive or neurological disorders did not present any significant correlation with the infection. In the case of reproductive disorders, there was also no association with positivity in the study by Moura et al. (2013). However, correlations between reproductive alterations and infection by the parasite were reported by Locatelli-Dittrich et al. (2006) and Abreu et al. (2014)

\section{Conclusions}

The results from the present study allow it to be stated that the southern part of the state of Minas Gerais is an enzootic area for $S$. neurona, $T$. gondii and Neospora spp., with a wide distribution of these parasites among Mangalarga Marchador horse farms. However, asymptomatic subclinical or chronic infection predominates in the region. Horizontal transmission seems to be the main form of infection for these parasites, and different factors are associated with seropositivity among horses. More research is needed in order to establish precisely which factors increase the risk of transmitting these agents, as well as to determine which species of Neospora ( $N$. caninum or $N$. hughesi) infects horses. 


\section{Acknowledgements}

To the Research Support Foundation of the State of Minas Gerais (Fundação de Amparo à Pesquisa do Estado de Minas Gerais, FAPEMIG), for financial support. To Dr. Luis Fernando Pita Gondim (UFBA), for the $S$. neurona merozoites, and to Dr. Ricardo Wagner de Almeida Vitor (UFMG), for the T. gondii tachyzoites. To Conselho Nacional de Desenvolvimento Científico e Tecnológico for research scholarship to C.M.B.M.R.

\section{References}

Abreu RA, Weiss RR, Thomaz-Soccol V, Locatelli-Dittrich R, Laskoski LM, Bertol MAF, et al. Association of Antibodies against Neospora caninum in mares with reproductive problems and presence of seropositive dogs as a risk factor. Vet Parasitol 2014; 202(3-4): 128-131. http://dx.doi. org/10.1016/j.vetpar.2014.03.022. PMid:24731383.

Alshahery MN, Mansour RS. Detection of Toxoplasma gondii antibodies in horses in Mosul, Iraq. Iraq J Vet Sci 2012; 26(2): 39-41.

Bártová E, Sedlák K, Syrová M, Literák I. Neospora spp. and Toxoplasma gondii antibodies in horses in the Czech Republic. Parasitol Res 2010; 107(4): 783-785. http://dx.doi.org/10.1007/s00436-010-1929-4. PMid:20532561.

Björkman C, Uggla A. Serological diagnosis of Neospora caninum infection. Int J Parasitol 1999; 29(10): 1497-1507. http://dx.doi.org/10.1016/ S0020-7519(99)00115-0. PMid:10608435.

Bruhn FRP, Daher DO, Lopes E, Barbieri JM, Rocha CMBM, Guimarães AM. Factors associated with seroprevalence of Neospora caninum in dairy cattle in southeastern Brazil. Trop Anim Health Prod 2013; 45(5): $1093-$ 1098. http://dx.doi.org/10.1007/s11250-012-0330-y. PMid:23212838.

Centro Panamericano de Zoonosis - CEPANZO. Procedimientos para estudios de prevalencia de enfermedades cronicas em El Ganado. Ramos Mejia; 1979.35 p. vol. 18. Nota Tecnica.

Ciaramella P, Corona M, Cortese L, Piantedosi D, Santoro D, Loria $\mathrm{AD}$, et al. Seroprevalence of Neospora spp. in asymptomatic horses in Italy. Vet Parasitol 2004; 123(1-2): 11-15. http://dx.doi.org/10.1016/j. vetpar.2004.05.022. PMid:15265566.

Corbellini LG, Smith DR, Pescador CA, Schmitz M, Correa A, Steffen DJ, et al. Herd-level risk factors for Neospora caninum seroprevalence in dairy farms in southern Brazil. Prev Vet Med 2006; 74(2-3): 130-141. http://dx.doi.org/10.1016/j.prevetmed.2005.11.004. PMid:16343669.

Duarte PC, Daft BM, Conrad PA, Packham AE, Gardner IA. Comparison of a serum indirect fluorescent antibody test with two western blot tests for the diagnosis of equine protozoal myeloencephalitis. J Vet Diagn Invest 2003; 15(1): 8-13. http://dx.doi.org/10.1177/104063870301500103. PMid:12580288.

Dubey JP, Howe DK, Furr M, Saville WJ, Marsh AE, Reed SM, et al. An update on Sarcocystis neurona infections in animals and equine protozoal myeloencephalitis (EPM). Vet Parasitol 2015; 209(1-2): 1-42. http:// dx.doi.org/10.1016/j.vetpar.2015.01.026. PMid:25737052.

Dubey JP, Schares G. Neosporosis in animals: the last five years. Vet Parasitol 2011; 180(1-2): 90-108. http://dx.doi.org/10.1016/j.vetpar.2011.05.031. PMid:21704458.

Dubey JP, Su C. Population biology of Toxoplasma gondii: what's out and where did they come from. Mem Inst Oswaldo Cruz 2009; 104(2):
190-195. http://dx.doi.org/10.1590/S0074-02762009000200011. PMid:19430643.

Dubey JP, Venturini MC, Venturini L, Mckinney J, Pecoraro M. Prevalence of antibodies to Sarcocystis neurona, Toxoplasma gondii, and Neospora caninum in horses from Argentina. Vet Parasitol 1999; 86(1): 59-62. http://dx.doi.org/10.1016/S0304-4017(99)00127-2. PMid:10489203.

Finger MA, Villalobos EMC, Lara MCCSH, Cunha EMS, Barros-Filho IR, Deconto I, et al. Detection of anti-Toxoplasma gondii antibodies in carthorses in the metropolitan region of Curitiba, Paraná, Brazil. Rev Bras Parasitol Vet 2013; 22(1): 179-181. http://dx.doi.org/10.1590/ S1984-29612013005000001. PMid:23459849.

Gennari SM, Esmerini PO, Lopes MG, Soares HS, Vitaliano SN, Cabral AD, et al. Occurrence of antibodies to Toxoplasma gondii and its isolation and genotyping in donkeys, mules, and horses in Brazil. Vet Parasitol 2015; 209(1-2): 129-132. http://dx.doi.org/10.1016/j. vetpar.2015.01.023. PMid:25747488.

Ghazy AA, Shaapan RM, Abdel-Rahman EH. Comparative serological diagnosis of toxoplasmosis in horses using locally isolated Toxoplasma gondii. Vet Parasitol 2007; 145(1-2): 31-36. http://dx.doi.org/10.1016/j. vetpar.2006.11.010. PMid:17174034.

Gondim LF, Lindsay DS, McAllister MM. Canine and bovine Neospora caninum control sera examined for cross-reactivity using Neospora caninum and Neospora hughesi indirect fluorescent antibody tests. J Parasitol 2009; 95(1): 86-88. http://dx.doi.org/10.1645/GE-1710.1. PMid:18613752.

Goodswen SJ, Kennedy PJ, Ellis JT. A review of infection, genetics and evolution of Neospora caninum: from the past to the present. Infect Genet Evol 2013; 13(1): 133-150. http://dx.doi.org/10.1016/j. meegid.2012.08.012. PMid:22985682.

Gupta GD, Lakritz J, Kim JH, Kim DY, Kim JK, Marsh AE. Seroprevalence of Neospora, Toxoplasma gondii and Sarcocystis neurona antibodies in horses from Jeju island, South Korea. Vet Parasitol 2002; 106(3): 193-201. http://dx.doi.org/10.1016/S0304-4017(02)00064-X. PMid:12062508.

Instituto Brasileiro de Geografia e Estatística - IBGE. Banco de Dados Agregados [online]. Brasília; 2013 [cited 2015 Dec 4]. Available from: http://www.sidra.ibge.gov.br

International Business Machines - IBM. IBM SPSS Statistics for Windows, Version 20.0. Armonk: IBM Corporation; 2011.

Johnson AL, Morrow JK, Sweeney RW. Indirect fluorescent antibody test and surface antigen ELISAs for antemortem diagnosis of equine protozoal myeloencephalitis. J Vet Intern Med 2013; 27(3): 596-599. http://dx.doi.org/10.1111/jvim.12061. PMid:23517480.

Kligler EB, Shkap V, Baneth G, Mildenberg Z, Steinman A. Seroprevalence of Neospora spp. among asymptomatic horses, aborted mares and horses demonstrating neurological signs in Israel. Vet Parasitol 2007; 148(2): 109113. http://dx.doi.org/10.1016/j.vetpar.2007.06.002. PMid:17614202.

Kouam MK, Diakou A, Kanzoura V, Papadopoulos E, Gajadhar AA, Theodoropoulos G. A seroepidemiological study of exposure to Toxoplasma, Leishmania, Echinococcus and Trichinella in equids in Greece and analysis of risk factors. Vet Parasitol 2010; 170(1-2): 170-175. http://dx.doi. org/10.1016/j.vetpar.2010.02.004. PMid:20197215.

Langoni L, Silva AV, Pezerico SB, Lima VY. Utilization of modified agglutination test and indirect immunofluorescent antibody test for the detection of Toxoplasma gondii antibodies in naturally exposed horses. BrazJ Vet Res Anim Sci 2007; 44(1): 27-32.

Laskoski LM, Muraro LS, Locatelli-Dittrich R, Abreu RA, Koch MO, Silva FT, et al. Ocorrência de anticorpos anti-Neospora caninum e anti- 
Toxoplasma gondii em equinos do Pantanal Mato-Grossense, Brasil. Semina Ciênc Agrar 2015; 36(2): 895-900.

Lins LA, Feijó LS, Nogueira CEW. Mieloencefalite protozoária equina nas regiôes da Campanha e do sul do Rio Grande do Sul no período de 1998-2006. Rev Ciênc Agrovet 2012; 11(3): 248-250.

Locatelli-Dittrich R, Dittrich JR, Richartz RRTB, Gasino Joineau ME, Antunes J, Pinckney RD, et al. Investigation of Neospora sp. and Toxoplasma gondii antibodies in mares and in precolostral foals from Paraná state, Southern Brazil. Vet Parasitol 2006; 135(3-4): 215-221. http://dx.doi. org/10.1016/j.vetpar.2005.10.010. PMid:16289863.

Lu ZM, Wang Y, Zhang ZY, Tang HW, Suo X. Evaluation of a indirect immunofluorescence assay kit for the detection of anti-Toxoplasma gondii IgG. Zhongguo Ji Sheng Chong Xue Yu Ji Sheng Chong Bing Za Zhi 2013; 31(5): 346-351. PMid:24818387.

Matsuo K, Kamai R, Uetsu H, Goto H, Takashima Y, Nagamune K. Seroprevalence of Toxoplasma gondii infection in cattle, horses, pigs and chickens in Japan. Parasitol Int 2014; 63(4): 638-639. http://dx.doi. org/10.1016/j.parint.2014.04.003. PMid:24780140.

Moré G, Vissani A, Pardini L, Monina M, Muriel M, Howe D, et al. Seroprevalence of Sarcocystis neurona and its association with neurologic disorders in Argentinean horses. J Eq Vet Sci 2014; 34(9): 1051-1054. http://dx.doi.org/10.1016/j.jevs.2014.06.002.

Morley PS, Traub-Dargatz JL, Benedict KM, Saville WJA, Voelker LD, Wagner BA. Risk factors for owner-reported occurrence of equine protozoal myeloencephalitis in the US equine population. J Vet Intern Med 2008; 22(3): 616-629. http://dx.doi.org/10.1111/j.1939-1676.2008.0082.x. PMid:18466255.

Moura AB, da Silva MO, Farias JA, Vieira-Neto A, Souza AP, Sartor AA, et al.. Anticorpos contra Neospora spp em equinos de duas regióes geográficas do Estado de Santa Catarina, Brasil. Rev Bras Parasitol Vet 2013; 22(4): 597-601. http://dx.doi.org/10.1590/S1984-29612013000400023. PMid:24473888.

Muller G, Brum JGW, Langoni PQ, Michels GH, Sinkoc AL, Ruas JL, et al. Didelphis albiventris Lund, 1841, parasitado por Ixodes loricatus Neumann, 1899, e Amblyomma aureolatum (Pallas, 1772) (Acari: Ixodidae) no Rio Grande do Sul. Arq Inst Biol (Sao Paulo) 2005; 72(3): 319-324.

Naves CS, Ferreira FA, Carvalho FSR, Costa GHN. Soroprevalência da toxoplasmose em equinos da raça Mangalarga marchador no município de Uberlândia, Minas Gerais. Vet Not 2005; 11(1): 45-52.

Noordhuizen JPTM, Frankena K, Thrusfield MV, Graat EAM. Application of quantitative methods in veterinary epidemiology. The Netherlands: Wageningen Pers; 2001.
Orr RT. Biologia dos vertebrados. São Paulo: Roca; 1986.

Pan W. Akaike's information criterion in generalized estimating equations. Biometrics 2001; 57(1): 120-125. http://dx.doi.org/10.1111/j.0006341X.2001.00120.x. PMid:11252586.

Paré J, Hietala SK, Thurmond MC. Interpretation of an indirect fluorescent antibody test for diagnosis of Neospora sp. infection in cattle. J Vet Diagn Invest 1995; 7(2): 273-275. http://dx.doi.org/10.1177/104063879500700222. PMid:7619917.

Patitucci AN, Pérez MJ, Cárcamo CM, Baeza L. Presencia de anticuerpos sericos contra Neospora caninum en equinos en Chile. Arch Med Vet 2004; 36(2): 203-206. http://dx.doi.org/10.4067/S0301-732X2004000200011.

Pitel PH, Romand S, Pronost S, Foucher N, Gargala G, Maillard K, et al. Investigation of Neospora sp. antibodies in aborted mares from Normandy, France. Vet Parasitol 2003; 118(1-2): 1-6. http://dx.doi.org/10.1016/j. vetpar.2003.10.007. PMid:14651869.

Pivoto FL, Macêdo AG Jr, Silva MV, Ferreira FB, Silva DAO, Pompermayer E, et al. Serological status of mares in parturition and the levels of antibodies ( $\mathrm{IgG}$ ) against protozoan family Sarcocystidae from their precolostral foals. Vet Parasitol 2014; 199(1-2): 107-111. http://dx.doi. org/10.1016/j.vetpar.2013.10.001. PMid:24183649.

Pusterla N, Tamez-Trevino E, White A, VanGeem J, Packham A, Conrad PA, et al. Comparison of prevalence factors in horses with and without seropositivity to Neospora hughesi and/or Sarcocystis neurona. Vet J2014; 200(2): 332-334. http://dx.doi.org/10.1016/j.tvjl.2014.03.014. PMid:24703324.

Sergeant ESG. Epitools epidemiological calculators [online]. Toowoomba: Australian Biosecurity Cooperative Research Centre for Emerging Infectious Disease; 2011 [cited 2015 Oct 29]. Available from: http:// epitools.ausvet.com.au

Stelmann UJP, Ullmann LS, Langoni H, Amorim RM. Equine neosporosis: search for antibodies in cerebrospinal fluid and sera from animals with history of ataxia. Rev Bras Med Vet 2011; 33(2): 99-102.

Stelmann UJP. Fatores associados à infecção por Sarcocystis neurona, Neospora spp. e Toxoplasma gondii em equinos da microrregião serrana do estado do Rio de Janeiro [Thesis]. Rio de Janeiro: Universidade Federal Rural do Rio de Janeiro; 2014.

Tassi P. Toxoplasma gondii infection in horses: a review. Parassitologia 2007; 49(1-2): 7-15. PMid:18412038.

Vidotto O, Kano FS, Freire RL, Mitsuka OL, Ogawa L, Bonesi G, et al. Ocorrência de anticorpos anti-Toxoplasma gondii em equinos procedentes de quatro estados (SP, PR, MS e MT) abatidos em Apucarana-PR. Semina: Ciênc Agrár 1997; 18(1): 9-13. 